\title{
Knowledge of Tourism Related to Halal Tourism in the City of Semarang in the Era of Pandemic
}

\author{
Nur Fauzan Ahmad ${ }^{1 *}$, Muhammad Hermintoyo ${ }^{1}$, and Alvina Maghfiroh ${ }^{1}$ \\ ${ }^{1}$ Faculty of Humanities, Diponegoro University, Semarang, Indonesia
}

\begin{abstract}
Religious awareness among Muslims is increasing. Halal has become a lifestyle for Muslims today, including tourism. The potential for the high number of Muslim tourists has encouraged the birth of the concept of halal tourism. Indonesia has declared itself a world halal tourist destination. Some of the tourist destinations are Central Java. The city of Semarang as the capital of Central Java has tourism potential that can be developed as a halal tourist destination. This study tries to see the level of knowledge of tourists from outside the city about halal tourism in the city of Semarang. The research data were collected through observation, interviews and documentation. Interviews were conducted with tourists in the city of Semarang who came from outside the city in a structured manner with a closed and open-ended question model. The research subjects were determined through purposive sampling. The collected data were analyzed by means of descriptive-qualitative. The research results are expected to provide input to the Semarang City Government in order to strengthen steps to make Semarang City a halal tourist destination.
\end{abstract}

\section{Introduction}

The tourism sector plays a vital role in the world economy because it contributes to employment growth and economic growth in any country. Tourism is also seen as one of the most important sources of Gross Domestic Product (GDP). The existence of an increase in the number of Muslim tourists is an opportunity and a challenge to improve the tourism sector [1]. This condition is an opportunity that needs to be used to increase state income. Therefore, various countries are competing to attract potential Muslim tourists.

In Islam, tourism activities are highly recommended; this tour instruction is found in various verses of the Al Quran.Among them are siyar, safar, al-siyahah al-ziyarah, or alrihlah. The Qur'an mentions the word al-siyâhah in several places, for example, in QS alTaubah: 2 \& 112.Surah al-An'am: 11-12 and al-Naml: 69-70 [2]. In Islam, tourism can be considered a form of worship such as an order to perform Hajj in certain months and Umrah, which is carried out throughout the year to the Baitullah. Tourism is also mandatory to seek and disseminate knowledge and learning, meditate and share admiration for Allah's creation [3].

* Corresponding author: fazwan.268@gmail.com 
The concept of halal has become the lifestyle of today's society [4]. Is the term "Islamic tourism / halal tourism" was first introduced to the public in 2000 at the OIC meeting as an alternative to meet the demand for tourism based on a lifestyle that suits the needs of a Muslim when travelling. Several terms are used, such as sharia tourism, Islamictourism, halal-friendly tourism destination, halal travel, Muslim-friendly travel destinations, halal lifestyle, and several other terms adjusted to the country's policies that developed it [5]. The term halal tourism is often confused with religious tourism and sharia tourism or halal tourism. The comparison of the three can be seen in the following table:

Table 1. The difference between conventional tourism, religious tourism and sharia tourism.

\begin{tabular}{|c|c|c|c|c|}
\hline No. & Aspect & $\begin{array}{c}\text { Travel } \\
\text { Conventional }\end{array}$ & Religious Tourism & Sharia / Halal Tourism \\
\hline 1. & Object & $\begin{array}{l}\text { Alam, culture, } \\
\text { Heritage, Culinary }\end{array}$ & $\begin{array}{l}\text { Tfour Worship, } \\
\text { Pleft out } \\
\text { History }\end{array}$ & All \\
\hline 2. & Taim & Cheer up & $\begin{array}{l}\text { Upgrade } \\
\text { Spirituality }\end{array}$ & $\begin{array}{l}\text { Increase spirituality } \\
\text { dith an entertaining way }\end{array}$ \\
\hline 3. & Target & $\begin{array}{l}\text { Touch } \\
\text { satisfaction and } \\
\text { pleasure in the } \\
\text { dimension of lust, } \\
\text { solely for } \\
\text { entertainment }\end{array}$ & $\begin{array}{l}\text { Spiritual aspect } \\
\text { which can be } \\
\text { soothing } \\
\text { jiwa. In order to } \\
\text { find peace of mind }\end{array}$ & $\begin{array}{l}\text { Fulfill the wishes and } \\
\text { pleasure and foster religious } \\
\text { awareness }\end{array}$ \\
\hline 4. & Guide & $\begin{array}{l}\text { Understand and } \\
\text { Master information so } \\
\text { that it can attract } \\
\text { tourists to tourist } \\
\text { objects }\end{array}$ & $\begin{array}{l}\text { Mastering history } \\
\text { figures and locations } \\
\text { that become tourist } \\
\text { objects }\end{array}$ & $\begin{array}{l}\text { Keep tourists interested } \\
\text { obyek at the same time } \\
\text { arouse the religious spirit of } \\
\text { tourists. } \\
\text { Able to explain the function } \\
\text { and role of sharia in the } \\
\text { form of happiness and inner }\end{array}$ \\
\hline 5. & $\begin{array}{l}\text { Amenities } \\
\text { Worship }\end{array}$ & Just a complement & Just a complement & $\begin{array}{l}\text { Become an integral part } \\
\text { dith tourism objects, } \\
\text { worship rituals become part } \\
\text { of the entertainment package }\end{array}$ \\
\hline 6. & Culinary & Umum & Umum & Specifics that are kosher \\
\hline 7. & $\begin{array}{l}\text { Relation } \\
\text { Communit } \\
\text { y and } \\
\text { Tourism } \\
\text { Object }\end{array}$ & $\begin{array}{l}\text { Complementary and } \\
\text { only for material gain }\end{array}$ & $\begin{array}{l}\text { Complementary and } \\
\text { only for material } \\
\text { gain }\end{array}$ & $\begin{array}{l}\text { Integrated, interaction based } \\
\text { pthere are principles of sharia }\end{array}$ \\
\hline 8. & $\begin{array}{l}\text { Agenda } \\
\text { Ptraveling }\end{array}$ & Every time & $\begin{array}{l}\text { Wact-time } \\
\text { certain }\end{array}$ & Pay attention to time \\
\hline
\end{tabular}

Source: Dini Andriani, et. al. (2015) [5].

So halal tourism is actually an ordinary tour, but it is endeavored to meet the needs of Muslim tourists.

Experts have different definitions of halal tourism as in the following table.

Table 2. Halal Tourism efficiency (Halal Tourism). 


\begin{tabular}{|l|l|}
\hline \multicolumn{1}{|c|}{ Author } & \multicolumn{1}{c|}{ Definition } \\
\hline Battour and Ismail [7] & $\begin{array}{l}\text { Kactivities in tourism that are permitted or permitted } \\
\text { according to Islamic teachings. }\end{array}$ \\
\hline Mohsin et al. [8] & $\begin{array}{l}\text { Pthe provision of tourism products and services that meet the } \\
\text { needs of Muslim tourists after the teachings of Islam. }\end{array}$ \\
\hline Halbase (2015) [9] & $\begin{array}{l}\text { Offer special tour packages and destinations to meet Muslim } \\
\text { considerations and needs kebutuhan }\end{array}$ \\
\hline
\end{tabular}

Halal tourism is tourism products and services in general but considering the needs of Muslims. Several things must be considered regarding the needs of Muslims, namely establishing prayers five times a day and a night, ensuring halal food and drinks, obliging fasting in the month of Ramadan and the existence of restrictions on men and women who are not mahrams. Therefore, the tourism business must accommodate this need if you want tourism that targets Muslims to sell well. Besides being related to whether or not to eat, this halal concept also refers to being clean. At least there are six needs of Muslim tourists related to religious principles that should be fulfilled by tourist destinations that want to become Muslim-friendly destinations, namely halal food, prayer places equipped with clean and holy ablution places, water to clean themselves in toilets, services during the month of Ramadan, non-activities halal and the existence of privacy for men and women [10].

At the end of 2016, the National Sharia Council (DSN) of the Indonesian Ulema Council (MUI) issued a fatwa regulating the implementation of sharia (halal) tourism, which could be used to develop the halal tourism sector in Indonesia. This fatwa regulates the entirety of sharia tourism activities, from the provisions of the contract (agreement) carried out, hotel provisions, tourist destinations, SPA, sauna, massage, travel agents, and provisions regarding tour guides [11].

Based on data from the 2015 Global Muslim Travel Index (GMTI), Indonesian Muslims have spent around US $\$ 7.5$ billion in the tourism sector, US $\$ 190$ in the halal food sector, and the US \$ 9.4 billion in the media and recreation sector. This figure is not directly proportional to the number of foreign Muslim tourists visiting Indonesia. Indonesia ranks sixth as a halal tourist destination in the Organization of Islamic Cooperation (OIC / OIC) destination group, after Qatar, Saudi Arabia, United Arab Emirates / UAE, Turkey, and Malaysia. For non-OIC countries, Singapore becomes the main destination of tourist destinations other than Thailand, England, South Africa, and France (MasterCard, \& Crescenrating, Global Muslim Tourism Index 2015") [12].

This is certainly a question for us together. Why is Indonesia not the main tourist destination? Even though the potential of Indonesia is large and the majority of the population is Muslim. According to Jetti Rosila Hadi, Deputy Chairman of the Indonesian Halal Lifestyle Center (Inhalec), halal industry tourism. There has not been any visible progress in Indonesia due to the absence of mapping and concrete strategies in developing and promoting halal tourist destinations in Indonesia, not optimal in handling, exploring and promoting potential, and lack of comprehensive research to determine policy direction. This ultimately makes halal tourism business actors go on their own without any common strategy. Even though halal tourism is related to services, there must be a collaboration between departments [13].

Therefore, it is necessary to research tourism potential in several regions in Indonesia, including those declared as one of the main halal tourist destinations in Semarang City as the capital of Central Java.

The city of Semarang is the capital of the province of Central Java, which is predominantly Muslim. According to BPS data for 2020, Muslims in Semarang City were 1,470,442 (87.7\%), Christian 116,744 (6.9\%), Catholic 86,365 (5.1\%), Buddhist 10,894 (0.6\%), Hindu 1236 (0.07\%), and 527 (0.03\%) (see table). 
Table 3. Number of Religious Adherents in the City of Semarang.

\begin{tabular}{|c|c|c|c|c|c|c|c|}
\hline \multicolumn{7}{|c|}{ Number of Religion Adherents (soul) } \\
\hline \multirow{3}{*}{ Amount } & Islam & Kconsistent & Hindu & Budha & Khatolic & Lainya & JAmount \\
\cline { 2 - 9 } & $1,470,442$ & 116,744 & 1,236 & 10,894 & 86,365 & 527 & $1,675,314$ \\
\hline
\end{tabular}

Source: BPS Semarang City 2020 (processed).

The social life of the people of Semarang City is very peaceful, even though its citizens are heterogeneous. The tolerance of religious life feels very high. These factors greatly support the security conditions. Semarang has become an excellent Indonesian city for investment and business development and is one of Indonesia's eight most livable cities. The Association of Indonesian Planning Experts (IAPI) survey results in 26 cities spread across 19 provinces[14].

This potential is utilized to continue to strive to develop halal tourism. This is supported by the geographical conditions of the exotic city of Semarang; there are upper and lower cities, which have sea and mountains. This high biodiversity makes Semarang City potential a halal tourist destination city. the tourist attractions offered are grouped into three things: nature tourism, cultural tourism, and artificial tourism [15].

The existence of Kota Semarang as a trading city and transit city also makes the city of Semarang has a rich cultural and historical heritage. The ethnic diversity of Javanese culture and Chinese, Arabic, and Dutch cultures is also the background of the tagline in Semarang City Branding, namely "Variety of Culture". The city of Semarang is developing while maintaining its heterogeneous and harmonious culture, which is symbolized by the mascot "Warak Ngendog", namely a mythological animal depicted as a symbol of unifying the three major ethnicities in Semarang. The body parts of the icon consist of Dragon (Chinese), Buroq (Arabic) and Goat (Javanese).

This cultural diversity is characterized by historical buildings that stand in the city of Semarang, which is one of the tourist attractions in the city of Semarang. Semarang City has 64 tourist objects/tourist attractions; 11 natural tourism, 24 cultural tourism 29 artificial tourism. Semarang, which has a variety of tourist attractions, raises the potential of Semarang as a MICE city (Meeting, Incentive, Convention, Exhibition) closely related to the trade and services sector, especially the tourism industry.

In the city of Semarang, lodging businesses have been established starting from homestays, inns, conventional hotels and sharia hotels whose existence strongly supports halal tourism facilities in the city of Semarang. However, it seems that this is still underdeveloped in the city of Semarang. This is because it is not easy to ensure halal food, halal certification, lack of facilitation and promotion. The city of Semarang has many tourist destinations, both natural, cultural and artificial, but the city of Semarang is still less attractive to local and foreign tourists.

Tourism is one of the sectors that play an important role in the success of regional autonomy. Therefore it is necessary to develop and utilize tourism resources and potential in the area. The condition of tourism potential and high attractiveness of Semarang City should make Semarang City a Halal Tourism Destination City.

This study aims to determine the level of knowledge and desires of tourists visiting Semarang City in 2021 regarding halal tourism and how to handle halal tourism during a pandemic which is expected to provide input for the Semarang City Government to make Semarang City a halal tourist destination.

\section{Methodology}


This research uses the purposive sampling method. Sampling was determined based on certain conditions by the research objectives, namely tourists from outside the city of Semarang, who had visited as tourists to Semarang, were over 20 years old.

To take a sample from the population, the Slovin formula is used.

Information:

$$
n=\frac{N}{1+N e^{2}}
$$

$\mathrm{n}=$ sample size

$\mathrm{N}=$ population size The number of tourists who enter the city of Semarang in 2021 is

$\mathrm{e}=$ allowance for inaccuracy because the tolerated sampling error is $10 \%$.

Based on data from the Semarang City Culture and Tourism Office in 2020, the number of tourists entering the city of Semarang was 3,266,931 consisting of 3,260,303 domestic tourists and 6,628 foreign tourists. Therefore, it is obtained that $n=99.87$, rounded up to 100 respondents.

Table 4. Data on tourists entering Semarang City in 2021.

\begin{tabular}{|l|l|l|l|l|}
\hline No. & Type of Traveler & $\mathbf{2 0 1 8}$ & $\mathbf{2 0 1 9}$ & $\mathbf{2 0 2 0}$ \\
\hline 1. & Indonesian tourists & $5,703,282$ & $7,223,529$ & $3,260,303$ \\
\hline 2. & Foreign tourists & 66,105 & 82,030 & 6,628 \\
\hline & Semarang city & $5,769,387$ & $7,305,559$ & $3,266,931$ \\
\hline
\end{tabular}

Source BPS 2021 [16].

The type of data used is qualitative and quantitative data. The data source of this research is primary data taken from respondents through the data collection process and secondary data taken from various sources, including related texts, internet sites and BPS data. Primary data were collected by field observations, direct interviews and questionnaires. The questionnaire uses closed and open questions. To measure the views of tourists on halal tourism in the city of Semarang, closed questions are used to answer yes and no or agree and disagree. Open-answer questions were used to measure their opinion about the facilities, motivation, and expectations of halal tourism.

This research uses descriptive statistical analysis. The data obtained from respondents is analyzed into percentages based on their specific characteristics by comparing the number of consumers multiplied by $100 \%$, which gets the highest percentage so that it is easier to read the data obtained.

\section{Results and Discussion}

This study found 100 respondents aged 20-64 years with the education level of respondents high school $9 \%$, D3 $=5 \%, \mathrm{~S}-1=48 \%$, S2 $=34 \%$. Meanwhile, based on the respondents' religion, the data obtained was $87 \%$ Islam, 9\% Christian, 2\% Catholic. Buddha 1\%. Based on the origin, $7 \%$ of respondents were found from abroad, $36 \%$ from outside Central Java, $41 \%$ from outside the city of Semarang, and 14\% from local Semarang.

Table 5. Data of tourists entering Semarang City in 2021.

\begin{tabular}{|l|l|l|l|l|}
\hline No. & Type of Traveler & $\mathbf{2 0 1 8}$ & $\mathbf{2 0 1 9}$ & $\mathbf{2 0 2 0}$ \\
\hline 1 & Indonesian tourists & $5,703,282$ & $7,223,529$ & $3,260,303$ \\
\hline 2 & Foreign tourists & 66,105 & 82,030 & 6,628 \\
\hline & Semarang city & $5,769,387$ & $7,305,559$ & $3,266,931$ \\
\hline
\end{tabular}

Source BPS 2021 [17].

Halal tourism is ordinary tourism; the difference is that there are additional facilities for Muslim tourists in the form of the availability of tourism products and services by Islamic 
rules or norms and the convenience of carrying out worship while on tour. It turns out that there are still many people who do not know about halal tourism. From the observations and direct interviews, it turned out that $90 \%$ answered that they never knew. This is different from an online questionnaire, most of whom answered that they had heard (68\%), a small proportion $(32 \%$ stated that they had not heard of the concept of halal tourism. Nearly half of more respondents (57\%) knew the concept of halal tourism.

There are still many people who consider halal tourism to be identical to religious tourism, specifically for Muslims (25\%). Even though the concept of halal tourism is very different from religious tourism. There are $21 \%$ of respondents who identified halal tourism as exclusive tourism for Muslims. It is not surprising that this has caused polemics in several regions, especially those where the majority are not Muslim. Non-Muslim tourists agree that the concept of halal tourism is applied in the city of Semarang. Almost all nonMuslim respondents (9\% Christian, 2\% Catholic. 1\% Buddhist) agreed with the concept of halal tourism. They are not bothered by this concept when applied. They are very happy with the halal concept, especially related to cleanliness, comfort, tourist attractions, the availability of water in separate toilets between women and men. as well as ensuring that food and beverages are not dangerous and safe for consumption because they do not contain harmful substances as a consequence of the halal concept. Only two respondents disagreed with the implementation of halal tourism, namely respondents from Africa who were Catholic because they did not understand the concept. See in (Table 6).

Table 6. Level of Knowledge of Tourists on the concept of Halal tourism.

\begin{tabular}{|l|l|l|l|l|}
\hline No. & Aspect & Yes & not & amount \\
\hline 1 & Never heard of the term halal tourism & $68 \%$ & $32 \%$ & $100 \%$ \\
\hline 2 & Knowing the term Halal Tourism & $57 \%$ & $43 \%$ & $100 \%$ \\
\hline 3 & Halal tourism = religious tourism & $26 \%$ & $74 \%$ & $100 \%$ \\
\hline 4 & Halal tourism = Muslim only & $22 \%$ & $78 \%$ & $100 \%$ \\
\hline 5 & Agree on the concept of halal tourism & $98 \%$ & $2 \%$ & $100 \%$ \\
\hline
\end{tabular}

Some people are still allergic to the word halal. They consider halal tourism synonymous with religious tourism (28\%) or exclusive tourism for Muslims (22\%). Halal tourism is not a threat. Halal tourism is also not exclusive to Muslims. Halal tourism does not need to change objects or create an Islamic atmosphere in tourist objects. Halal tourism only adds facilities that are not detrimental to other tourists; instead, it provides comfort, cleanliness, and security, which is very beneficial for all tourists.

All respondents answered that they agreed that the city of Semarang was used as a halal tourist destination. Therefore they propose the addition of prayer facilities that represent places for ablution that are clean and have enough water for washing, clean and safe facilities, halal culinary markers, separation of male and female toilets. Tourists expect the completeness of halal tourism facilities. In general, they want to improve facilities, especially the availability of adequate worship facilities (89\%), both in a strategic, comfortable, spacious place, guaranteed safety and cleanliness and the availability of water for purification. There are still several tourist objects that do not meet the requirements for the availability of representative prayer places supported by toilets and ablution places that are comfortable, clean and have enough water. This condition can be seen in the Old City Area. Many visitors complained about the lack of a prayer room and comfortable toilets separate for men and women.

In addition, not all tourist objects are supported by culinary delights that are halal. Even though most of the respondents $(62 \%)$ want the availability of a culinary place that is guaranteed cleanliness and halalness. Indeed, there are several stalls around the tourist attraction where food and beverage sellers are selling, but on average, there is no halal 
certificate from the MUI. Halal information is also poorly communicated, especially in tourism promotion, even though some respondents got information about tourist destinations in Semarang City from googling on the internet (62\%) and social media (66\%).

Most of the out-of-town respondents still rely on information from social media $(64 \%)$ and googling from the internet (64\%), recommendations from friends $(52 \%)$ and conventional media such as TV, radio, newspapers (9\%).

Things that attract respondents from outside the city of Semarang and even abroad to Semarang City are the existence of historical places (55\%), good instragamable areas for taking pictures $(40 \%)$, good food $(40 \%)$, safe $(29 \%)$, community-friendly, exotic place $(32 \%)$.

Halal tourism is intended for Muslims and all people who are not bound by religion, ethnicity, race, and others. The essence of halal tourism is extended service atau form of full service to tourists. It does not eliminate all the elements found in conventional tourism. Halal tourism is Muslim-friendly tourism. So it is not tourism that is halal. However, Muslim tourists have "faith-based needs" that must be met when travelling when they enter the city of Semarang; they are facilitated by a place of worship that is comfortable and clean, and that eating and drinking facilities are guaranteed halal.

Halal tourism requires clean and comfortable facilities for prayer and ablution because Muslim tourists have an obligation to pray five times a day and night. Halal tourism also requires guarantees of halal and clean food and drinks. This is, of course, also needed by non-Muslim tourists because the concept of halal is identical to being clean, holy and not harmful to the body, so it is suitable for consumption [18]

therefore, the objects, both cultural tourism objects, culinary tours, and events that are held, have provided an attraction to attract both local and foreign tourists. Joint promotion related to marketing Semarang City tourism has been optimal and maximal enough to make the people of Semarang City and its surroundings know about the annual events in Semarang City and the location of the events held.

Regarding tourism in the pandemic season, respondents expect tourism objects to be opened with the implementation of strict health protocols $(53 \%)$. The reason is that there is already a vaccine, society is already bored, so the community's economy is moving. Others (47\%) stated that it should be closed because the pandemic had not disappeared and tourism was not a primary need. However, in reality, many respondents found that the implementation of health protocols was not strict (69\%), while $30 \%$ stated that tourism objects had not implemented health protocols properly. The application of the concept of halal tourism is exact, especially about the application of health protocols. The application of health protocols is by Islamic law principles, namely maqasidus-sharia, hygienic principles in all matters, availability of water for washing hands, availability of healthy food and drinks, clean and halal is needed not only for Muslim tourists but also for nonMuslims. The implementation of health protocols during this pandemic is very much by the Islamic worldview [19]

According to Indriyasari, Head of the Semarang City Culture and Tourism Office, a pandemic is an important moment to generate halal tourism. In current conditions, people cannot travel far, especially abroad. This is an opportunity that the city of Semarang should capture to become a domestic tourist destination. The goal is not to increase the number of tourists but to improve the quality of the tours so that tourists stay entertained and feel safe so that they want to come to Semarang by implementing optimal health protocols. Even though it is still in a pandemic condition, the growth of the tourism industry in Semarang has now begun to stretch. Many restaurants, cafes, and hangout places have sprung up, especially the upper-middle segment of society. This is a sign that tourism is starting to rise. Currently, more than 60 hotels, restaurants, and tourist attractions have bagged the 
CHSE certificate. This label can add to the safety and comfort of tourists when they come to Semarang. [20]

Pandemic makes tourism demanded to lead to a more responsible direction for visitors, for example, maintaining health and ethics in tourist destinations. Halal tourism also leads to healthy themes and consuming halal, healthy and clean food. According to Riyanto Sofyan, Chair of the Indonesian Halal Tourism Association (PPHI), this condition is an opportunity for halal tourism to rise faster because its characteristics are by the current mega tourism trend.

However, in reality, health protocols have not been strictly implemented at tourist sites. $69 \%$ of respondents stated that the health protocol at tourist sites in Semarang City had not been strictly implemented. Based on field research, researchers still found many clustered tourists, and there was no special officer to remind them. The rules for using masks tend to be obedient; handwashing stations and soap are also available. However, the awareness of tourists not to crowd is hard to avoid. During field observations in the Kota Lama Area, officers were walking around carrying loudspeakers reminding tourists to wear masks and not crowd. However, in another place, the officer was not found. This is a challenge in itself for tourism managers, including the government.

\section{Conclusion}

The conclusion is 1) Halal has become a lifestyle for people today, including halal tourism.

2) The city of Semarang can become a halal tourist destination with exotic natural conditions and unique cultural diversity, high carrying capacity for the community and tourists. 3) The level of knowledge of tourists on halal tourism is still low. 4) Not all of the supporting facilities for halal tourism have been appropriately provided by tourism managers in Semarang. 5) The existence of halal tourism in the pandemic season is, in fact, very supportive of the hygienic aspects of food and beverages and the cleanliness of tourist sites that are by the Muslim world view. Especially during this pandemic, halal tourism can be opened by implementing strict health protocols.

The government of Semarang City is advised to continue to improve and seriously improve and develop tourist objects in support of this halal tourism program by (1) providing facilities for Muslim tourists such as providing representative prayer facilities and sufficient water for purification and halal assurance. Food and beverages, and the privacy of tourists (2) in collaboration with the Indonesian Ulema Council (MUI) and the Halal Assurance Management Agency (BPJH) and the Food and Drug Supervisory Agency (BPOM) to obtain halal product certification for culinary and restaurant business actors to ensure halal food and beverage and culinary products around tourist sites, (3) in collaboration with tourism entrepreneurs, travel agencies, hotels and restaurants to promote the existence of halal tourism to the public, (4) Conducting promotions and socialization through social media and events to introduce and understand about halal tourism, as well as making halal tour packages to the Travel Agency (5) strictly enforcing health protocols at a tourist location.

Researchers would like to thank the Dean of FIB who has supported this research, the Department of Culture and Tourism of the City of Semarang for making this research possible.

\section{References}

1. Satriana, et.al., Halal Tourism: Development, Chance And Hallenge, Journal Of Halal Product And Research (JHPR), 01(02), May-November (2018) 
2. H. bin Muhammad bin Husain Naqur, al-Ahkam al-SiyahahwaAtsaruha: Dirasah Syar'iyyah Muqaranah, Dar Ibn al-Jawzi Riyadh, 15 (1424 H)

3. Jaelani, Halal Tourism Industry in Indonesia: Potential and Prospect, MPRA Paper, 76237 (2017)

4. H. Adinugraha, H. Hermawan, M. Sartika, A. H. A. Ulama'i, Halal Lifestyle In Indonesia, Journal of Islamic Economics An-Nisbah, 05(02), April (2019)

5. F. A. A. Hasan, Organizing Halal Tourism in Indonesia (Analysis of DSN-MUI Fatwa on Guidelines for Implementation of Tourism Based on Sharia Principles), in the Journal of Sharia and Law El Ahkam, 2(1), January-June (2017)

6. D. Andriani, et al., Initial Report on the Study of Sharia Tourism Development. Ministry of Tourism of the Republic of Indonesia Jakarta (2015)

7. M. Battour, M. N. Ismail, Halal Tourism: Concepts, Practices, Challenges and Future, Tourism Management Perspective, 19, 150-154 (2016)

8. A. Mohsin, , N. Ramli, B. A. Alkhulayfi, Halal Tourism: Emerging Opportunities, Tourism Management Perspective, 19, 137-143 (2016).

9. Halbase, Halal Tourism (2015) Retrieved from: http://www.halbase.com/articles?content=11

10. Shahid, A. Rosyidi, Muslim Tourists: Prospects, Development \& Needs (2018) Retrieved from: https://studipwisata.com/

11. F. A. Al Hasan, The Implementation of Halal Tourism in Indonesia (Analysis of the DSN-MUI Fatwa on Guidelines for Organizing Halal Tourism Based on Sharia Principles, Al Ahkam Journal of Sharia and Law Sciences, 2(1), 60-93 (2017)

12. MasterCard, Crescenrating, Global Muslim Tourism Index 2015 (March, 2017) Retrieved from: www.crescenrating.com

13. Interview with Deputy Chair of Inhalec (2021)

14. Ayo Semarang (2021) Retrieved from: www.AyoSemarang.com

15. K. G. Widagdyo, Analysis of the Halal Tourism Market in Indonesia, The Journal of Tauhidinomics, 1(1), 73-80 (2015)

16. BPS Semarang City, Semarang Municipality in Figure 2021 (2021)

17. BPS Semarang City, Semarang Municipality in Figure 2021 (2021)

18. A. Jaelani, Halal Tourism Industry in Indonesia: Potential and Prospect, MPRA Paper, 76237 (2017)

19. Maulana, A. M. Rizal, Pandemic in Islamic Worldview; From Conception to Conspiracy, Journal of Islamic Thought Tridevotion, 31(3), 301-339 (2020)

20. Interview with the Head of the Semarang City Culture and Tourism Office (May, 2021) 